\title{
A prequel to the Dantean Anomaly: the precipitation seesaw and droughts of 1302 to 1307 in Europe
}

\author{
Martin Bauch $^{1}$, Thomas Labbé ${ }^{1,3}$, Annabell Engel ${ }^{1}$, and Patric Seifert ${ }^{2}$ \\ ${ }^{1}$ Leibniz Institute for the History and Culture of Eastern Europe (GWZO), Leipzig, Germany \\ ${ }^{2}$ Leibniz Institute for Tropospheric Research (TROPOS), Leipzig, Germany \\ ${ }^{3}$ Maison des Sciences de l'Homme de Dijon, USR 3516 CNRS, Dijon, France
}

Correspondence: Martin Bauch (martin.bauch@uni-leipzig.de)

Received: 3 March 2020 - Discussion started: 20 May 2020

Revised: 2 October 2020 - Accepted: 5 October 2020 - Published: 25 November 2020

\begin{abstract}
The cold/wet anomaly of the 1310s ("Dantean Anomaly") has attracted a lot of attention from scholars, as it is commonly interpreted as a signal of the transition between the Medieval Climate Anomaly (MCA) and the Little Ice Age (LIA). The huge variability that can be observed during this decade, like the high interannual variability observed in the 1340s, has been highlighted as a side effect of this rapid climatic transition. In this paper, we demonstrate that a multiseasonal drought of almost 2 years occurred in the Mediterranean between 1302 and 1304, followed by a series of hot, dry summers north of the Alps from 1304 to 1306. We suggest that this outstanding dry anomaly, unique in the 13th and 14th centuries, together with cold anomalies of the 1310s and the 1340s, is part of the climatic shift from the MCA to the LIA. Our reconstruction of the predominant weather patterns of the first decade of the 14th century - based on both documentary and proxy data - identifies multiple European precipitation seesaw events between 1302 and 1307, with similarities to the seesaw conditions which prevailed over continental Europe in 2018. It can be debated to what extent the 1302-1307 period can be compared to what is currently discussed regarding the influence of the phenomenon of Arctic amplification on the increasing frequency of persistent stable weather patterns that have occurred since the late 1980s. Additionally, this paper deals with socioeconomic and cultural responses to drought risks in the Middle Ages as outlined in contemporary sources and provides evidence that there is a significant correlation between pronounced dry seasons and fires that devastated cities.
\end{abstract}

\section{Introduction and state of the art}

In recent decades, scholars of medieval studies have produced considerable research reconstructing the Little Ice Age (LIA) (Pfister et al., 1996) and appraising the impacts of cold events on pre-modern societies; however, except for the notable exception of economic historians, few scholars have addressed the issue of droughts (Stone, 2014). Almost two decades ago, Brown (2001) has highlighted the so-called Dantean Anomaly as a wet and cold anomaly lasting from 1315 to 1321 that led to famine over northwestern Europe (Jordan, 1996). This climatic anomaly has been recently described more neutrally as "the 1310s event" (Slavin, 2018). A distinctive " 1300 event" has been found in proxy data even around the Pacific rim (Nunn, 2007). Historians have consistently focused on the cold, wet character of this decade, seemingly fascinated by continuous rains and their often detrimental impacts on food security. A lot has been written, for example, about how excessive rain in 1315 and 1316 caused harvests to fail and ultimately resulted in a famine in northern Europe (Campbell, 2016; Jordan, 1996).

However, as modern worries about global warming and the possibility of more frequent drought events like what occurred in 2003 have grown, dry periods have found more and more interest among climate historians (Brázdil et al., 2019; Brázdil et al., 2018; on the Middle Ages: Rohr et al., 2018). Most of this research, though, deals with the early modern period (Garnier, 2019; Munzar, 2004; Martín-Vide and Barriendos Vallvé, 1995; Weikinn, 1965/66), especially with the "millennium drought" of 1540 (Pfister, 2018; Wetter and Pfister, 2013; Wetter et al., 2014). Concerning the medieval 
period, the very recent publication on a specific drought year like 1473 (Camenisch et al., 2020) is still an exception, preceded only by case studies on medieval droughts in Hungary and modern-day Croatia (Kiss, 2017; Kiss and Nicolić, 2015). In fact, the socioeconomic impacts of droughts on medieval societies are more difficult to determine than those linked with cold, wet weather. In most parts of western Europe, droughts were largely benevolent, for agricultural production in these areas centered around cereals and wine (Le Roy Ladurie, 2004), which easily tolerate dry conditions as long as the hydric stress does not block vegetation growth, as it did in extreme cases like 1540. Droughts thus rarely induced socioeconomic disasters in comparison with those frequently associated with wet anomalies. As Pribyl (2017) states, for example, warm, dry summer half years did not generally endanger crops in medieval England. Only after the introduction of Yersinia pestis in 1348 do such summers - ideal conditions for flourishing rodent populations - show an indirect statistical correlation with epidemics occurring the following year. In Mediterranean regions, droughts must have posed a graver danger for crops and had a greater impact on the food supply and living standards, due to a higher vulnerability to lack of water. However, few studies have addressed this topic.

Many climate historians generally date the onset of the transition period from the Medieval Climate Anomaly (MCA) towards the LIA to the turn of the 14th century, and the time around $1300 \mathrm{CE}$ sees the nadir of the Wolf minimum in solar forcing (Steinhilber et al., 2009). Although these periods are highly disputed and maybe only regionally applicable (Andres and Peltier, 2016; Grove, 2001; Pfister et al., 1996), this consensus has prompted researchers to emphasize mainly the cold, wet conditions of the 1310s. This article does not intend to add to the discussion over whether the MCA and LIA actually occurred and, if so, when the LIA started (Bradley et al., 2003; White, 2014), but it does seem worth examining at least the consistently dry decade (at least during the summers) which directly preceded the wet, cold period of the 1310s. In fact, in the first decade of the 14th century, two successive major drought events of at least supraregional scale affected Europe: one striking Italian regions and another impacting regions north of the Alps. This article aims both to reconstruct their duration, extent, and severity and to examine the related socioeconomic impacts and sociocultural reactions. It also provides an approximate timeline of the underlying meteorological patterns and contextualizes these anomalies by comparing them to similar events reported between 1200 and $1400 \mathrm{CE}$.

In 1304, in the conclusion of the annual report, the anonymous author of the Greater Annals of Colmar, a Dominican monk most interested in weather phenomena, stated with astonishment: "[This past] winter [i.e., 1303-1304] was cold in Rome, but in Alsace it was warm, and on the contrary, [the year before, i.e., 1302-1303] it was warm in Rome, but cold in Alsace" (Jaffé, 1861, p. 229). It is not only winter tem- peratures that acted like a north-south seesaw at the beginning of the 14th century all over Europe. As we will demonstrate, there was an even more pronounced precipitation seesaw from 1302 to 1307 , with extremely dry conditions in the Mediterranean from the end of 1302 to early 1304, while normal humidity levels prevailed north of the Alps, and pronounced drought periods from 1304 to 1307 in most parts of western and central Europe. We will examine if this double event might have been the longest, multi-seasonal drought by far in three European regions during the 13th and 14th centuries. Our reconstruction of this period is based on documentary and proxy data on northern and central Italy (IT), eastern France (FR) and central Europe (CE) (Fig. 1). There is a dearth of studies on the cultural impacts of drought on medieval societies, but particularly in regard to the Italian and French material, we can provide some initial insights into the economic impacts and stress these droughts imposed on medieval societies and how they adapted with measures like firefighting and infrastructure to improve access to water and food.

The article is structured as follows: Sect. 2 describes and evaluates the data sets taken from written and proxy records. Section 3 provides an overview of the applied methodologies of climate and drought indices and the reconstruction of agricultural production. In Sect. 4, we present our indices reconstruction and the meteorological patterns identified in the period in question. Furthermore, we compare the chronology of major fires and droughts and identify the cultural and societal impacts of droughts. Section 5 discusses the reliability of narrative sources compared to dendrochronological data, the impacts of drought on agriculture, the development of new institutional structures to prevent and fight fires, and the global context of this period. We conclude that the 13021307 drought period resembles the 2018-2019 European precipitation seesaw and can be interpreted as an indicator of rapid climate change in the early 14 th century.

\section{Data}

\subsection{Narrative sources}

Climate historians have long regarded narrative texts as most important sources of information and, over the course of decades, have carefully catalogued relevant events as described in chronicles and annals. This paper draws principally on these previous works. Alexandre (1987), Curschmann (1900), and Weikinn (1958, 2017) each provided information, and mostly also a reliable critical apparatus, for the territories of present-day France, Italy, and central Europe. Brázdil and Kotyza (1995, Appendix I) gathered material on the Czech Republic, as did Malewicz (1980) for Poland. For Italy, where more urban chronicles were produced than elsewhere in Europe, we collected material ourselves but also incorporated some material from Emanuela Guidoboni's (Bologna) unpublished collection, which covers 
the period of 1000-1500 CE with about 200 edited narrative sources, some compilations and thematic articles, and some limited archival material. We chose to use only those sources in the Guidoboni collection that were taken from critical editions of contemporary chroniclers. For France, there are few chronicles, which almost solely cover the regions of Paris and Alsace during this epoch (Alexandre, 1987).

\subsection{Administrative sources}

Central sources for the history of climate are municipal protocol books and financial records, which provide a wealth of information regarding extreme weather events and their impacts on communal structures and agrarian production. Such records of city officials' decisions and deliberations were kept in Italian archives beginning in the mid-13th century. Matters of justice, economy, local policy, and the social order were systematically noted after each meeting of the town council. Local governments sometimes had to deal with situations created by climatic stress, for example, by organizing grain imports in the event of shortfalls, resolving potential social disorders that such shortages caused, organizing processions together with ecclesiastical authorities, or dealing with the disruption of water mills in cases of floods or droughts. For the city of Siena, we used the unpublished protocols of the consiglio generale for the years 1302-1307 (Bowsky, 1981).

In France and Germany, such documentation does not exist before the mid-14th century. Nevertheless, archives contain a rich assortment of unedited financial documents for the territory of the County of Savoy, similar to those that historians of climate have repeatedly used to reconstruct the situation in England (Titow, 1960; Pribyl et al., 2012; Pribyl, 2017). Roll accounts produced by the county administration starting from the end of the 13th century provide continuous information about the impact of extreme weather events on local estates' agrarian profits. Wine and cereal production, as well as food prices, fluctuated significantly in response to climatic stress in the medieval economy (Pribyl, 2017; Camenisch, 2015), and yields and annual variations in price thus serve as an indicator of climatic trends. Moreover, the accountants who were responsible for the production of these rolls often referred explicitly to climatic events to justify declines in revenue. As a result, such documents allow for a detailed chronology of events, which we have reconstructed in this case for the region of Bresse (FR).

\subsection{Charters}

Charters are an established source for reconstructing Hungarian climate history (e.g., Kiss, 2019, 2016; Vadas, 2010). A preliminary search within edited German charters and the Regesta Imperii does not reveal explicit evidence of drought conditions, but these sources do include several instances related to major fires: indulgences, for example, helped finance

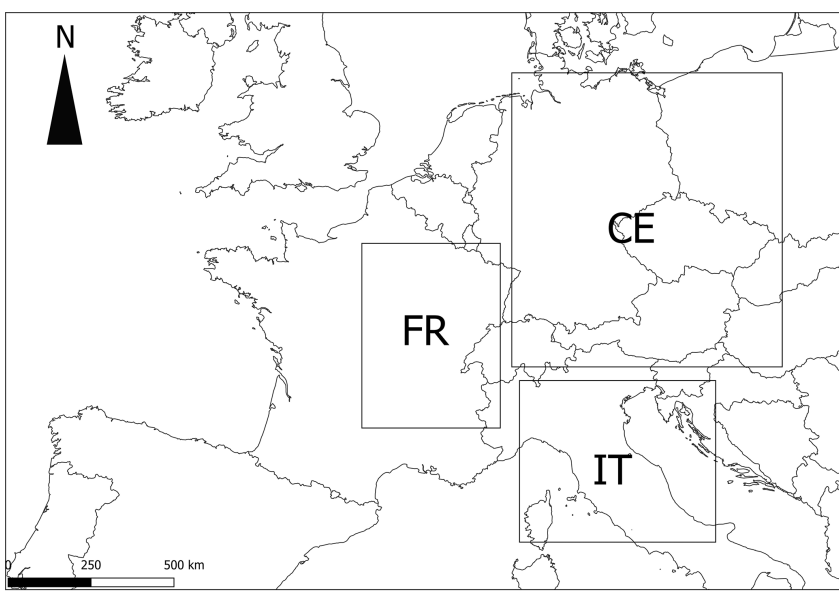

Figure 1. Geographical zones delimited for documentary research (map: Thomas Labbé).

the reconstruction of a number of buildings destroyed in such fires. In such cases, unfortunately, the charters normally lack an exact date for the events and therefore only enable the determination of a terminus ante quem.

\subsection{Information from manuals}

In this research into fires and their connection to weather and climate, we supplemented the information taken directly from chronological accounts by examining instructional literature, following the example set for early modern history by Zwierlein (2011), whose research evaluates German and Austrian Städtebücher (lit., "city books"; Keyser, 19391974; Knittler et al., 1968-2001). For most of the cities included, there is a list of historical fires - unfortunately of ten without information about severity or causes, and always without references. Nonetheless, this huge database is a unique source of information, especially for the statistical evaluation of fires and their potential connection to droughts. The Städtebücher provide a trove of sources for medieval urban history that historians consider generally reliable. The present study also incorporates more detailed information about fires from manuals on historical monasteries (Klosterbücher, e.g., Huschner et al., 2016).

\section{Methodology}

\subsection{Reconstruction from narrative sources and the creation of climate indices}

Using well-established methodologies (Pfister, 1999; Brázdil et al., 2013; Glaser, 2013; general overview: Pfister et al., 2018) as a general guide, we have compiled climate indices on precipitation and temperature for the period 1290 1320 that show the dry and hot episodes addressed in this study within the climatic context of the surrounding three 
decades. The established indexing methodology was adapted mainly in regard to the temporal scale, as we chose a semiannual approach ("growing season" vs. "non-growing season") that corresponds to the structure of medieval documentary records based on agricultural cycles. Derived from these well-established climate indices (see Supplement 1), we closely followed Camenisch and Salvisberg (2020) and created seasonal drought indices from the aforementioned narrative sources over the longer period (1200-1400) for all three regions (IT, FR, CE) (see Supplement 1). As the sources and climate historical repositories focus on extreme events, we gave values of -3 (extremely dry) and -2 (very dry) if we had actual indicators of agricultural and meteorological drought (Brázdil et al., 2019, p. 75) or a lack of precipitation over 2 months. However, we have not applied the category of “ socioeconomic drought" (Brázdil et al., 2019, pp. 7576 ), as not all of its indicators are in our opinion specifically related to dry periods. To identify long-term droughts, these drought index values have been calculated for single years (Figs. 8-10) over the course of two centuries, which provides the context in which the extraordinary character of the 13021307 drought events becomes particularly apparent. Whenever possible, these indices have been compared with a treering-based precipitation reconstruction to reassess the quality of the index reconstruction and the reliability of the available dendrochronological data for FR, IT, and CE. Beyond these core regions, however, the historical record does not generally permit for more than a comparison of isolated cases with scientific proxy data. England is a notable exception, as Pribyl (2017) shows in her research on the situation there.

\subsection{Agricultural production in France and England from administrative documentation}

Based on financial documents for the Bresse region (FR), we have reconstructed wheat and wine yields for the period of 1300-1330. For each of these reconstructions, the raw data of individual castellanies - i.e., administrative units under the control of a steward - have been extracted and then compiled in aggregate series indexed on the year 1307. Grain yields have been estimated from the revenue generated on seignorial lands located in the territories of two castellanies (Jasseron and Treffort). Although these accounts refer only to the taxes paid by the tenants who cultivated these lands rather than directly indicating the quantity of grain harvested each year, there is no reason to discount the reliability of the reconstructed series entirely. Wine yield series are much less problematic, as these accounts do list the exact volume of wine produced in seignorial vineyards located in four castellanies. Thus, roll accounts allow for the reconstruction of a detailed chronology how local vineyards fared under varying climatic conditions. This reconstruction can then be compared with existing research on English wheat yields (Campbell, 2007) and East Anglian (July-September) precipitation as reconstructed by Pribyl (2017).

\subsection{Drought periods and city fires}

Thus far, it is scholars of medieval cultural history who have primarily addressed urban fires in the Middle Ages (Jankrift, 2003, 83-100; Riegg, 2003; Wolf, 2015; Wozniak, 2011, 2015), but some have pointed to a likely connection between drought and fire for extreme years like 1540 (Pfister, 2018; Wetter et al., 2014; Mauelshagen, 2010, pp. 127-129). Although Zwierlein (2011, pp. 102-110) has questioned the connection, the latent fire risk of timber frame buildings with open fires to heat, cook, and provide light is more than obvious (Bitterli, 2015; Contessa, 2000, pp. 16-18). Even contemporaries made the connection between drought and fires: "Many cities were consumed by domestic fires because of the drought and 'sterility' (sterilitas) that prevailed in this year" (Wattenbach, 1851b, p. 641). We have been comparing accumulated drought indices, distinguishable by seasons, with the number of fires we could determine based on documentary data (see Sect. 2.1, 2.3, and 2.4). These are taken for FR from Alexandre (1987), for IT from the unpublished Guidoboni collection, and for CE mainly from charters (see Sect. 2.3), chronicles, and the German Städtebücher and comparable manuals (see Sect. 2.4).

\subsection{Sociocultural reactions}

Finally, we want to highlight how medieval societies dealt with and adapted to drought beyond the classical rogation ceremonies and other religious processions (overview of Brázdil et al., 2019), especially as we have only one example of such rituals in IT: in May 1303, there were processions for rain in Parma that indeed "provoked" one rainy day (Bonazzi, 1902 , p. 84). There is, however, considerably more to be considered about how droughts impacted medieval societies, and about how those societies perceived and reacted to their situation. This qualitative analysis progresses on three fronts: developments in infrastructure as a reaction to drought, cultural artifacts related to the experience of drought, and social responses to dry periods.

\section{Results}

\subsection{Indices reconstruction and qualitative analysis in combination with proxy data}

The precipitation indices taken by themselves (Fig. 2) suggest a sustained dry period in Italy that lasted nearly 2 years but is not at all represented by the Palmer Drought Severity Index (PDSI) values from the Old World Drought Atlas (OWDA; Cook et al., 2015). The case of Italian OWDA data is special, as only a handful of dendrochronological series from the Alps and Calabria are available for the period in question. This reinforces existing doubts about the reliability of the simulated precipitation values (Bothe et al., 2019), which were calculated for large parts of Italy for the OWDA 
on the basis of only a few tree-ring series. The precipitation indices for FR (Fig. 3) are scarce, and yet they show a pronounced drought pattern in the growing seasons of 13041306. In regard to IT, we lack information on the continuity of this drought over the non-growing seasons (1303-1304 to 1306-1307), but the general tendency agrees with available OWDA data, except for the summers of 1293 and 1311.

The most interesting results are the precipitation indices for CE (Fig. 4): they have to be stacked, as CE includes a number of quite different subregions, but all of these regions display similar trends, which, moreover, are mostly consistent with OWDA data points. Where the indices do seem to differ (e.g., 1291-1292, 1294-1295, 1305-1306), they provide precipitation data on the non-growing season which is not covered by tree rings.

Regarding the qualitative description of weather patterns, documentary data provide a clear, reliable, and very dense picture (see Supplement 2) of meteorological conditions over the period in question. The summer of 1302 was extraordinarily rainy in $\mathrm{CE}$ and $\mathrm{FR}$, which experienced floods, but Italy received very little precipitation in the second half of 1302. This was followed by a cold winter in CE, FR, and IT, in which major rivers (Rhine, Doubs, Adige) froze and water levels dropped unusually low, while areas further east (Silesia, Russia) experienced a mild and snowless winter. The spring of 1303 proved cold in CE - and while we have no information on this summer from north of the Alps, IT endured a meteorological, agricultural, and hydrological drought for all of 1303. The following winter (1303-1304) was particularly warm in FR, while conditions in $\mathrm{CE}$ varied from warm in its western regions to cold in Bohemia. Meanwhile, IT is reported to have had a very chilly winter with freezing rivers. The spring and summer of 1304 were extremely dry and hot in FR and CE, with all signs of hydrological drought. IT saw significant, yet short, precipitation events in late spring, interrupting the 13 months of drought, and then another dry summer until September 1304. Once more, a pronouncedly cold winter in 1304-1305 followed in FR and CE, with strong precipitation in IT in early 1305 that continued into summer, while FR faced another dry period in the summer of 1305 . The winter of 1305-1306 was so chilly that the Baltic Sea froze over, as did rivers in FR, CE, and IT. In FR, drought continued into the spring of 1306, and, in both CE and IT, the winter of 1306-1307 was again very cold, followed later by flooding. In eastern CE, drought set in during the summer of 1307, as a heat wave swept across FR and IT.

If we look beyond the core regions of this study to the Middle East, we see that Syria and Egypt also experienced drought conditions in $1304-1306 \mathrm{CE}$, with rogation processions for rain in Damascus (Vogt et al., 2016, p. 91; Raphael, 2013, pp. 96-96) and low water levels along the Nile (Chalyan-Daffner, 2013, p. 565 and 668; Vogt et al., 2016, p. 91). While documentary data for the Byzantine area in regions between Italy and the Middle East do not mention drought between 1302 and 1307 (Telelis, 2004,
Vol. 2, pp. 626-627), proxy data from the Aegean basin can help: a reconstruction of annual precipitation based on North Aegean tree rings (Griggs et al., 2007) suggests that the years 1302-1304 are among the five driest periods of the 13th and 14th centuries in this region. We might thus describe the drought event not only as supraregional but even perhaps as a phenomenon of transcontinental scale.

\subsection{Agricultural production in France and England}

Figure 5 plots the reconstruction of mean wheat and wine yields in Bresse (FR) from 1300 to 1320. Both lines show a similar pattern, namely a trend to relatively high yields before 1310 and then a downward trend reflecting the deteriorating weather conditions of the 1310s anomaly. Good harvests, especially for wine, clearly stand out in 1304 and 1305 , in response to the successive droughts locally described in both Parisian and Alsatian chronicles (see Supplement 2). In addition, a contemporary chronicle (Jaffé, 1861, p. 231) confirms the plentiful wine harvest of 1304. In the years 1306 and 1307, vineyards' production was fairly average, even though historical accounts mention heat waves in June and/or July of both years - i.e., generally favorable conditions for vineyards. In these years, however, temperatures were so high that peasants could not plow the vineyard on time, which might explain why production was lower than the previous years. In any case, financial documents from Bresse for 1304 to 1307 suggest above-average summer temperatures. Such a link between wine production and warm growing seasons exists for 1313, as well, when account records mention that the vineyard had benefitted from a dry summer.

Figure 6 plots the relationship between grain production in southern England (Campbell, 2007) and the Bresse region against East Anglian July-September precipitation indices as reconstructed from local archival sources (Pribyl et al., 2012; Pribyl, 2017). From 1300 to 1320, English and French yields correlate significantly (Pearson coefficient $r=0.61$ ). General trends are similar in the two regions, with average or above-average harvests in the 1300s. Moreover, we find a synchronous movement between 1304 and 1306 (Fig. 6), reflecting the precipitation trend. The low level of precipitation reconstructed in East Anglia for these three specific years is most likely similar for the Bresse region, which means that this multiannual 1304-1306 drought probably affected a large part of northwestern Europe.

\subsection{Identification of meteorological patterns}

The proxy and documentary data presented in Sect. 4.1 and 4.2 provide evidence for the occurrence of an alternating series of large-scale weather patterns over large parts of Europe between 1300 and 1310. The features found are similar to the phenomenon of a water seesaw, which Toreti et al. (2019) have recently discussed in relation to the drought events of 2018 and others over the last five centuries. A wa- 


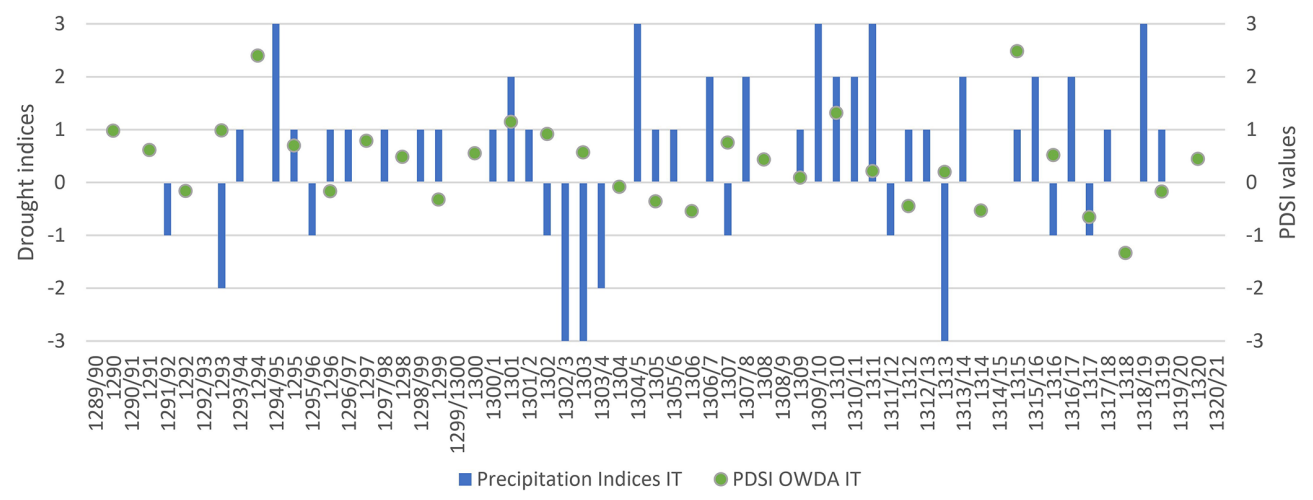

Figure 2. Reconstructed semi-annual drought indices and OWDA PDSI data for JJA from tree rings (Cook et al., 2015) for IT, 1290-1320.

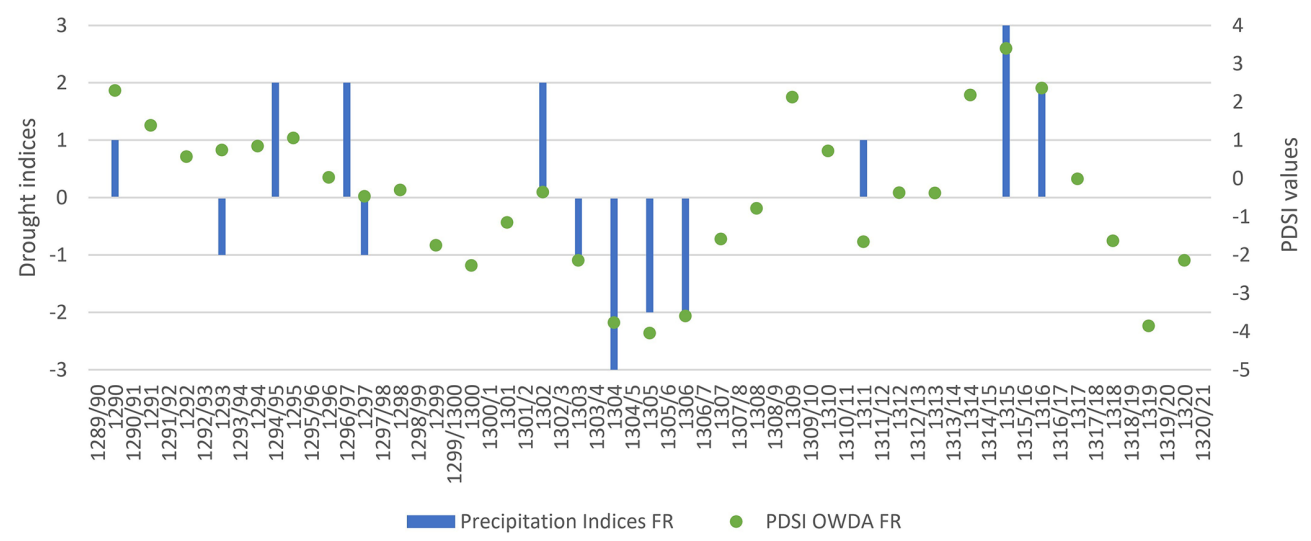

Figure 3. Reconstructed semi-annual drought indices and OWDA PDSI data for JJA from tree rings (Cook et al., 2015) for FR, 1290-1320.

ter seesaw, hereinafter more specifically referred to as a precipitation seesaw, describes a remarkable dipole of negative precipitation anomalies in one part of Europe and positive ones in another part. Toreti et al. (2019) associated the 2018 drought with pronounced positive anomalies in the geopotential height of the $500 \mathrm{hPa}$ level of atmospheric pressure over the continental European landmass north of the Alps. This blocking situation led to the formation of low-pressure anomalies over both northern and southern Europe; as a result, central Europe suffered a severe lack of precipitation, whereas northern and southern Europe experienced excessive precipitation. In the 2018 case, the precipitation seesaw was thus positive over southern Europe and negative over central Europe.

Similar to what Toreti et al. (2019) reported, the predominant weather patterns found for the period from 1302 to 1307 also must have resulted from certain seesaw constellations and associated patterns in the geopotential height fields. We used the reported weather conditions collected for this study (see Supplement 2) to establish the large-scale meteorological patterns by means of the $500 \mathrm{hPa}$ geopotential anomalies for the period under study, which are depicted in Fig. 7a$\mathrm{k}$ and described in the following: in the summer of 1302 (Fig. 7a), wet conditions in FR and CE and dry conditions in
IT correspond to a precipitation seesaw which was negative over IT and positive over FR and CE. Geopotential anomalies were thus positive over IT and negative over FR and CE. The winter of 1302-1303 (Fig. 7b) was reportedly dry and cold over IT, FR, and CE, but warm over western Russia. This situation can be explained by the presence of a blocking large-scale positive anomaly in the $500 \mathrm{hPa}$ geopotential that covered all of IT, FR, and southern CE. A negative anomaly over northern Europe would generally correspond to the arrival of warm conditions and moisture in Silesia and Russia; in fact, reports confirm above-average temperatures but neglect any mention of precipitation. While the evidence suggests that the potential seesaw was tipping from the region CE, IT, and FR (negative) towards eastern (central) Europe i.e., towards Silesia and Russia (positive) - there are insufficient precipitation proxies for Silesia and Russia during this period, meaning that this constellation can be hypothesized but not currently proven.

The 1302-1303 winter constellation likely continued throughout 1303 (Fig. 7c). In the spring, continued positive $500 \mathrm{hPa}$ geopotential anomalies over IT, FR, and CE brought an enduring cold period north of the Alps, while the blockage led to a continued lack of precipitation over IT. Also in the following winter of 1303-1304 (Fig. 7d), the positive 


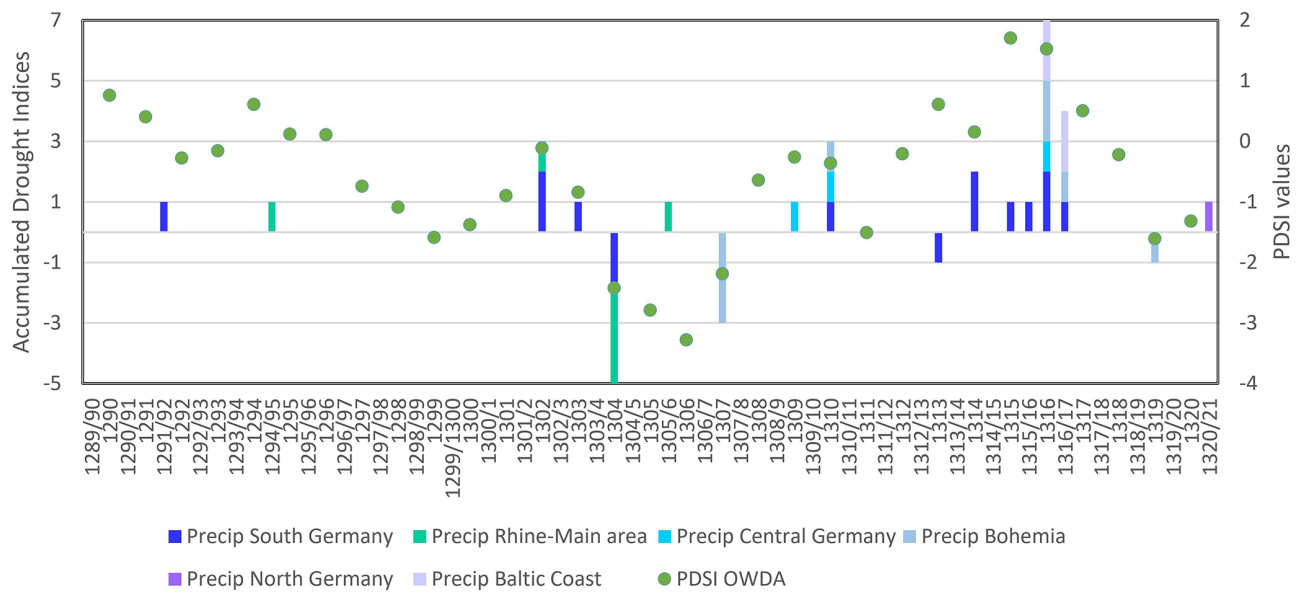

Figure 4. Reconstructed semi-annual drought indices and OWDA PDSI data for JJA from tree rings (Cook et al., 2015) for CE, 1290-1320.

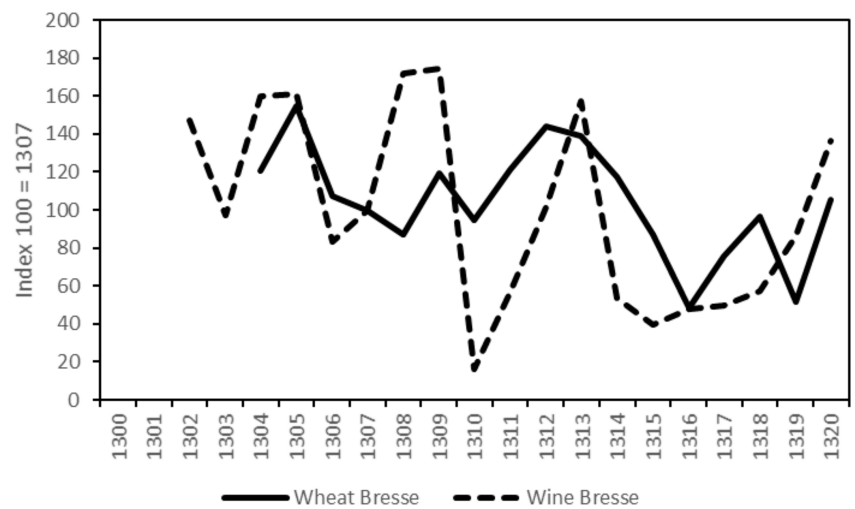

Figure 5. Mean wheat and wine yields in the region of Bresse (FR), 1300-1320.

$500 \mathrm{hPa}$ geopotential anomaly must have persisted over IT. However, the warm conditions reported in FR and western CE indicate that the positive anomaly did not extend as far to the north as it had the previous winter.

The spring of 1304 seems to have been a turning point for the precipitation seesaw constellation (Fig. 7e). The combination of dryness in FR and CE and wetness reported for IT suggests that the positive $500 \mathrm{hPa}$ geopotential anomaly had moved towards FR and CE (similar to what Toreti et al., 2019, found in the case of the 2018 drought), enabling precipitation systems to reach IT from the southwest via the western Mediterranean. The dry summer reported for IT following the wet spring could have been caused by a slight positive $500 \mathrm{hPa}$ geopotential anomaly over IT during this time (Fig. 7f), but, given the subtropical climate, summertime precipitation is rather unlikely anyway.

The weather reported for the winter of 1304-1305 clearly indicates the presence of a large-scale positive $500 \mathrm{hPa}$ geopotential anomaly over northern Europe and a negative $500 \mathrm{hPa}$ geopotential anomaly over southern Europe

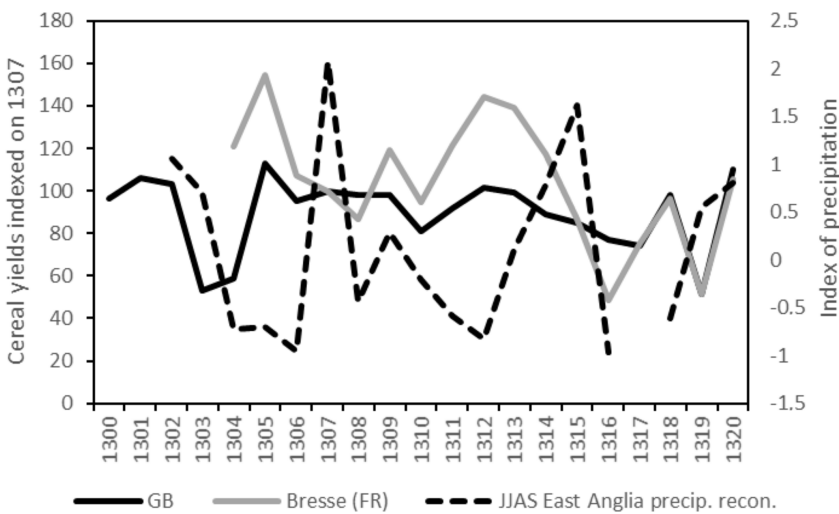

Figure 6. Comparison of cereal production in southern England and the Bresse region (FR). Data: southern England wheat yields (Campbell 2007); Bresse wheat yields (this article); East Anglia JJAS precipitation reconstruction (Pribyl, 2017).

(Fig. 7g). Cold air masses from eastern Europe were reported for the whole of CE and FR, while Italian sources reported wet conditions. This constellation likely continued during the summer of 1305, with a slightly increased negative anomaly over eastern CE that allowed normal temperatures and precipitation over this region (Fig. 7h).

Cold air masses were reported throughout CE, FR, and IT in the winter of 1305-1306, which must have been caused by yet another large-scale positive $500 \mathrm{hPa}$ geopotential anomaly over northern Europe (Fig. 7i) and the associated cold, easterly winds along its southern boundary. A negative $500 \mathrm{hPa}$ geopotential anomaly can thus be expected over northern Africa. The resulting westerly flow of eastern European air masses over CE consequently led to the dry conditions reported for FR. That situation likely continued until the winter of 1306-1307, when drought and low temperatures were once again reported for CE and IT (Fig. 7j). The increasing flood conditions reported in IT in the spring 
(a) Summer 1302

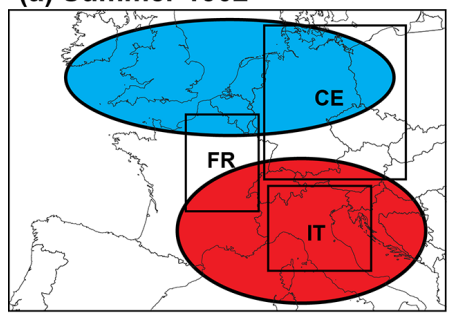

(d) Winter 1303/04

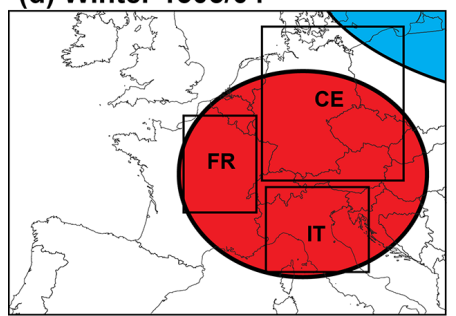

(g) Winter 1304/05

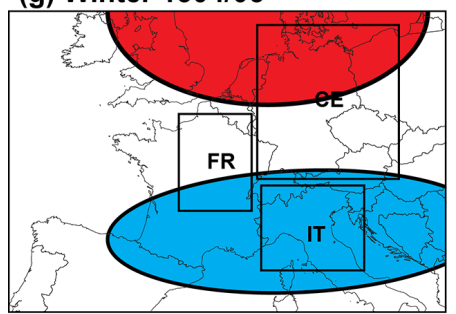

(j) Winter 1306/07

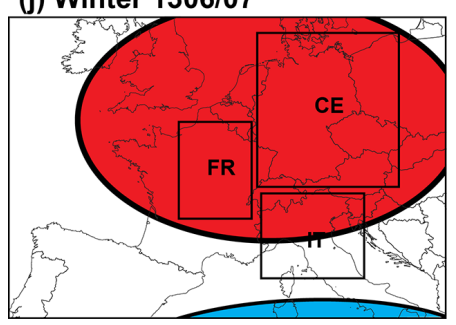

(b) Winter $1302 / 03$

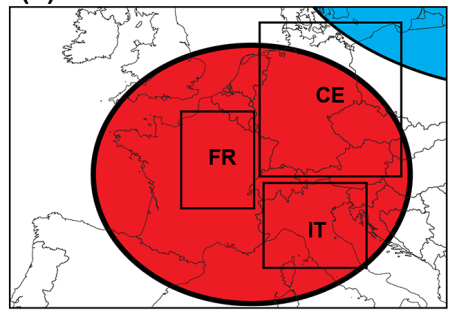

(e) Spring 1304

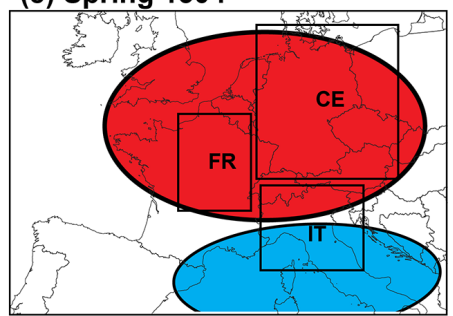

(h) Summer 1305

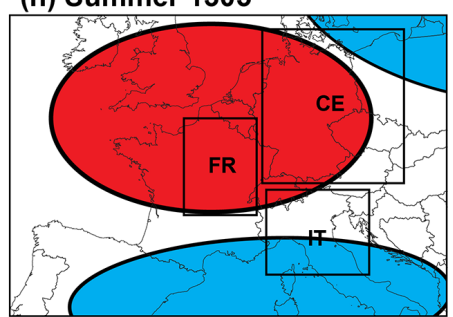

(k) Summer 1307

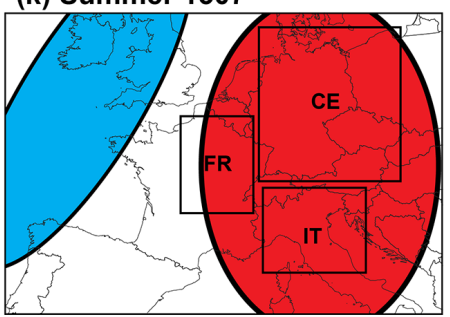

(c)Summer 1303

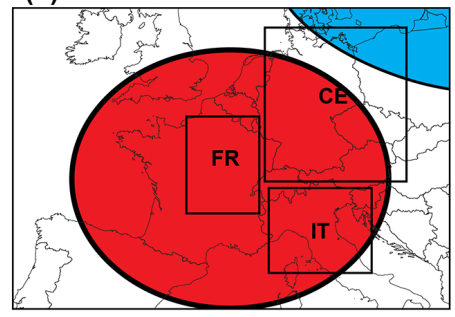

(f) Summer 1304

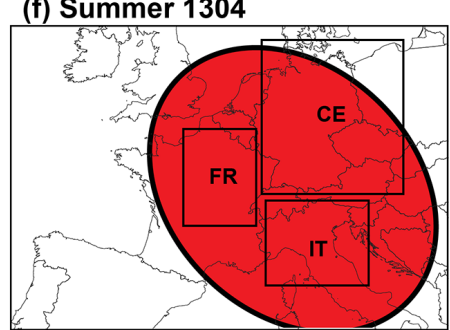

(i) Winter $1305 / 06$

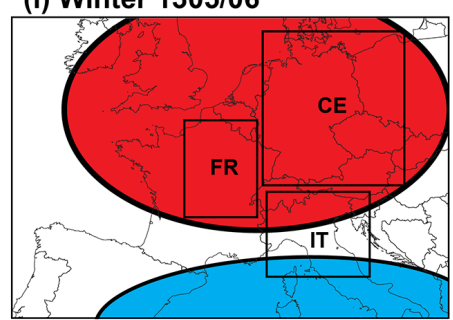

positive $500 \mathrm{hPa}$
geopot. anomaly

negative $500 \mathrm{hPa}$ geopot. anomaly

Figure 7. Illustration of the possible constellations of the $500 \mathrm{hPa}$ geopotential anomaly that can explain the weather patterns retrieved from the proxy and documentary sources for the years 1302-1307.

of 1307 can be explained either by snowmelt or by a slight shift of the positive $500 \mathrm{hPa}$ geopotential anomaly towards the north, allowing precipitation systems to reach IT via the Mediterranean.

Finally, the drought in CE and heat wave in FR and IT are likely a result of a continuing positive $500 \mathrm{hPa}$ geopotential anomaly over CE (Fig. 7k). Dryness prevailed in its center, while on the western (FR) and southern (IT) borders hot air was advected from Africa.

\subsection{Fires correlating with drought periods and cultural aspects}

A peak in urban fires during the 1302-1305 drought is visible for IT (Fig. 8), with a significant correlation of droughts and fires $(r=0.346)$ in the 13th and 14th centuries. A similar peak is visible for FR in 1306 (Fig. 9) with an even higher correlation of fires and droughts $(r=0.657)$ over this time period. The correlation of drought years and fires in CE (Fig. 10) is less obvious but still significant $(r=0.379)$. Furthermore, suspecting from these results (Figs. 8-10) that the probability of a fire might lag 1 year behind drought events because wooden structures that had dried over long periods might ignite more easily even after the drought had ended, we cross-correlated the data to test this assumption and found a very significant correlation regarding a 1-year lag for FR $(r=0.83)$ and a significant one for IT $(r=0.59)$ but none for CE $(r=-0.167)$. The differing results in the case of CE can probably be explained by discrepancies in the documentary data in the Deutsche Städtebücher, while the relevant information on fires in IT and FR could be more carefully validated by historical source criticism.

As the OWDA information for CE (broadly defined here as a rectangle naturally delineated by the Rhine and the 


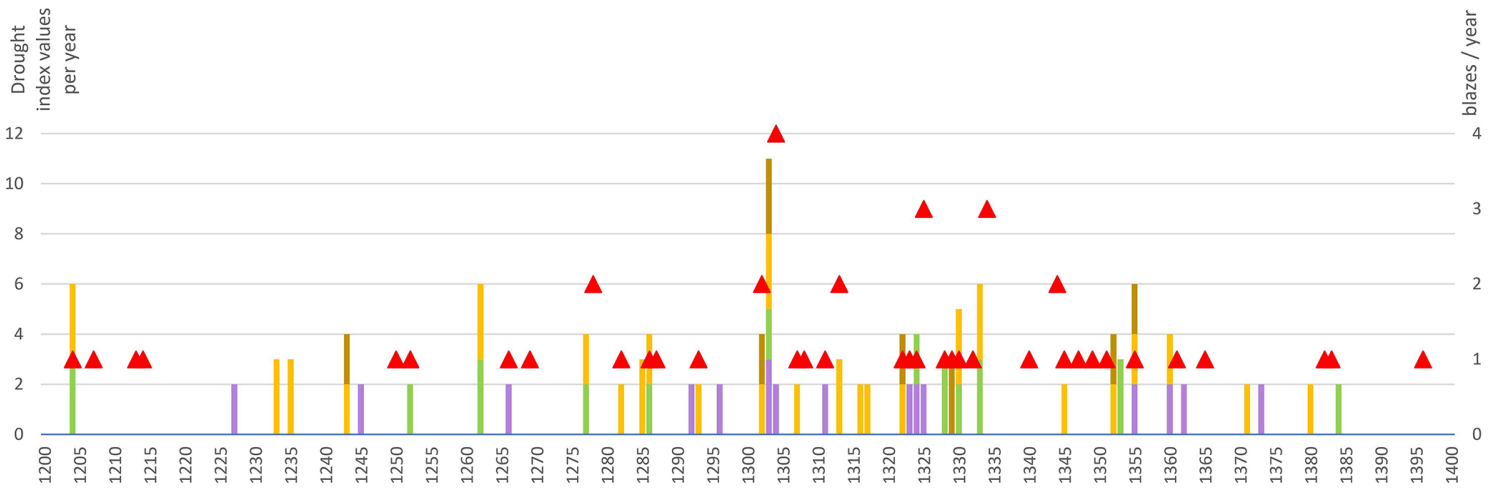

Winter (DJF) drought $\quad$ Spring (MAM) drought $\quad$ Summer (JJA) drought $\quad$ Autumn (SON) drought $\quad \Delta$ Blazes (IT)

Figure 8. Reconstruction of drought indices compared with a chronology of fires for IT, 1200-1400. Data are available for 64 years out of 200 (32\% coverage).

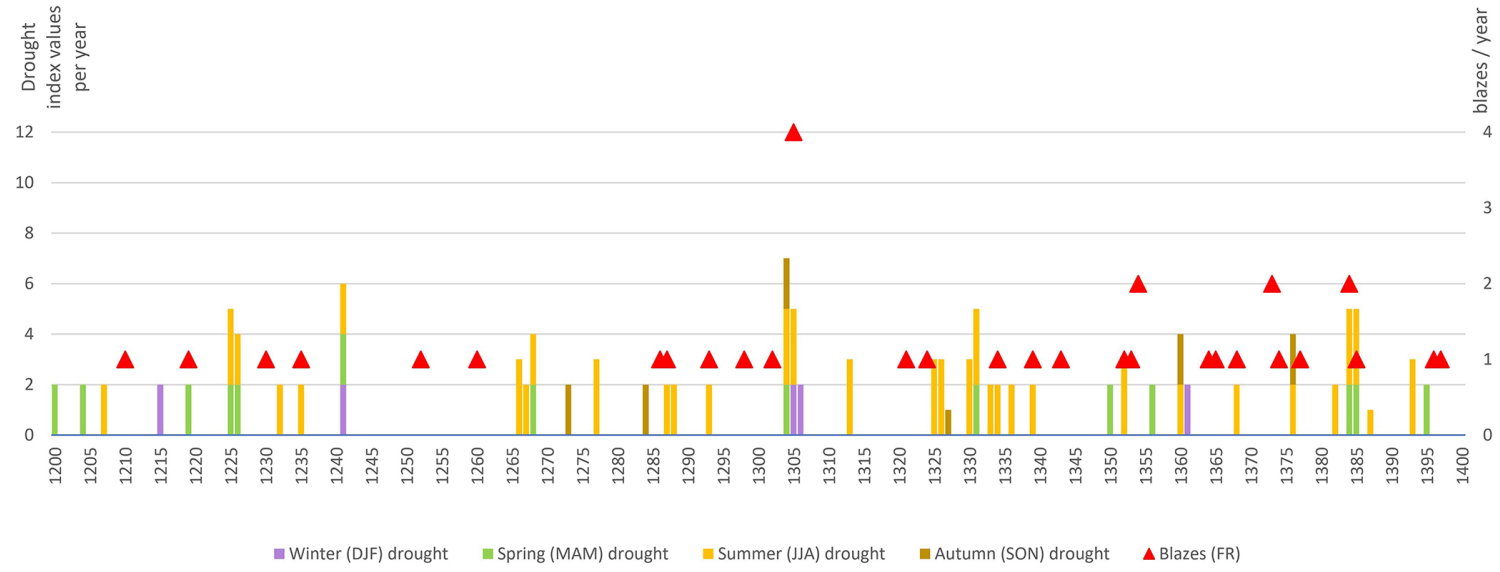

Figure 9. Reconstruction of drought indices compared with a chronology of fires for FR, 1200-1400. Data are available for 67 years out of $200(33.5 \%$ coverage).

Alps to the west and south, and stretching to Novgorod in the east and including all of Denmark plus southern Scandinavia to the north, i.e., $47.34-58.69^{\circ} \mathrm{N}, 7.52-30.88^{\circ} \mathrm{E}$ ) is relatively dense and reliable, it has been combined with available information on fires from documentary data. Nevertheless, the correlation of low PDSI values (i.e., drought) and fires (Fig. 11) is very weak in this case, if not nonexistent $(r=-0.06)$.

The best documented of all fires during the 1302-1307 period is the infamous city fire of Florence on 10 June 1304 in which 1700 homes burned. Contemporaries suspected a conspiracy of the political opposition, the Florentine White Guelfs, who were driven out of the city in the aftermath of the fire. The detailed documentation available on 14th century fires in Florence (Contessa, 2000, pp. 89-107) makes it clear how unusual a fire of this magnitude was, even for a populous city like the Tuscan metropolis. Later, 1 week after the fire, and again in early August 1304, the fire was even the topic of homilies delivered by the Dominican Giordano da Pisa, who reminded his fellow citizens that the fire had only done God's will: with fire came warmth, and, when it burned the city's houses, this was product of divine volition (Varanini and Baldassari, 1993, p. 314). Another strategy to cope with the fire threat was to oblige citizens, in the event of drought or strong winds, to place buckets of water by the doors of their houses, ready to be used immediately by anyone in the event of fire emergency. A Parisian chronicler described such a coping mechanism in 1305, when high temperatures combined with strong wind made authorities worry about a potential disaster (Buchon, 1827, pp. 116-117). Other sources share this concern as well (Wattenbach, 1851a, p. 676). That wind played a crucial role can be deduced from the fact that fires were able to cross water bodies like rivers (Wozniak, 2015).

\subsection{Drought and infrastructural responses}

A number of infrastructural responses to the drought experience of 1302-1304 are evident in Italy. In 1303, the city 


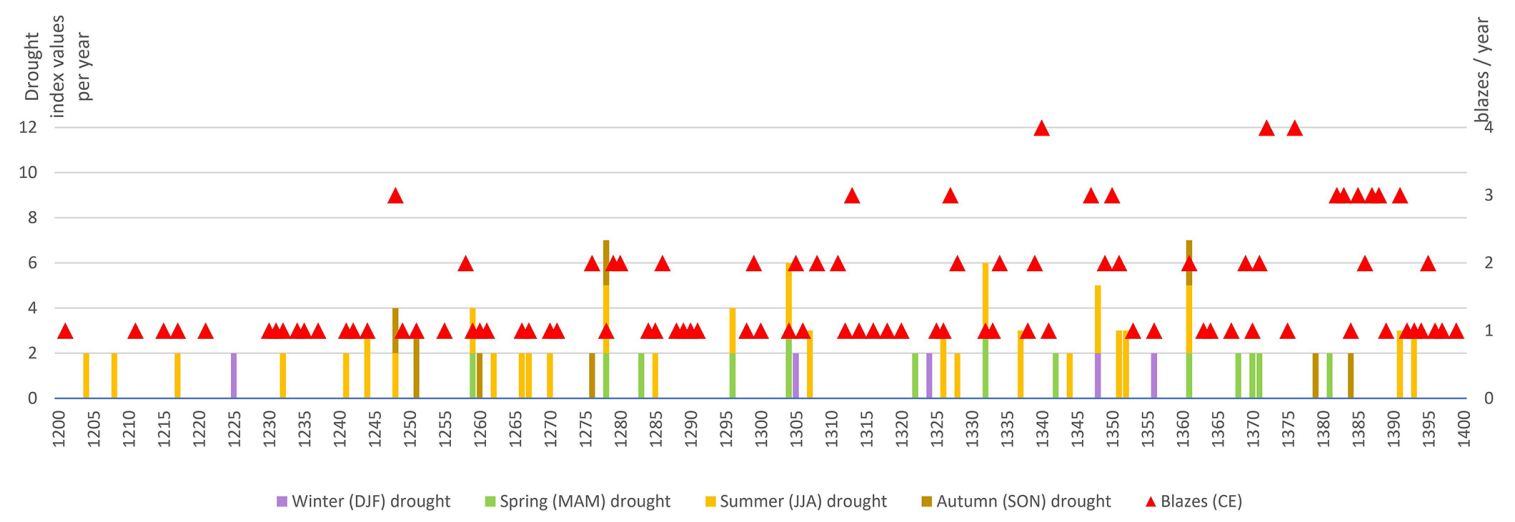

Figure 10. Reconstruction of drought indices compared with a chronology of fires for CE, 1200-1400. Data are available for 125 years out of 200 (62.5\% coverage).

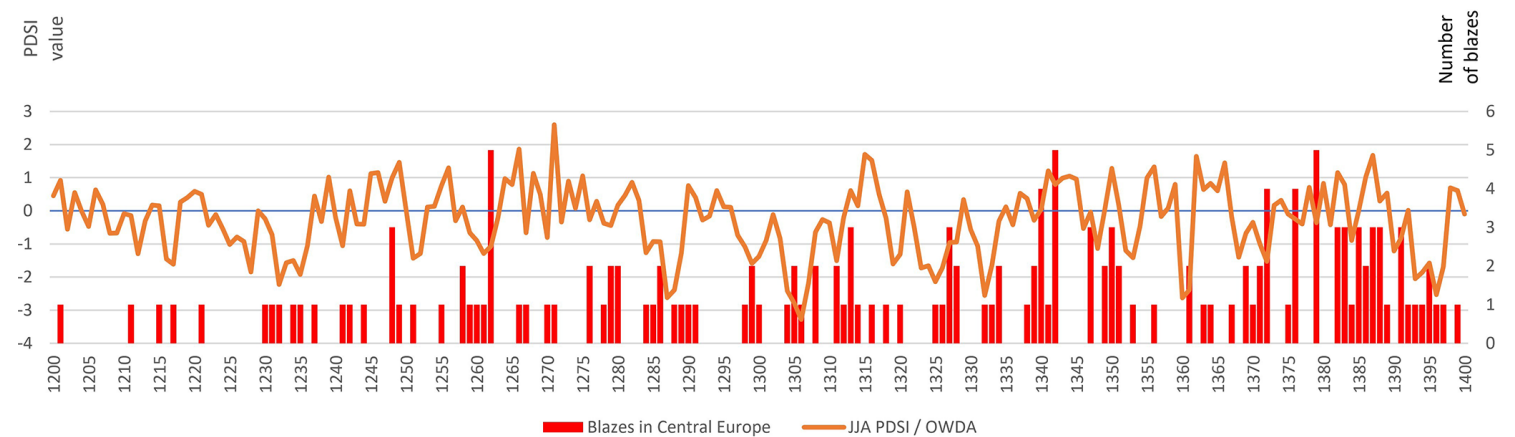

Figure 11. Reconstruction of JJA precipitation in tree rings for CE and information on fires from documentary data for the same region.

of Parma built a new fountain, larger and deeper than before (Bonazzi, 1902, p. 86). The Tuscan city of Siena, situated far from any larger bodies of water and frequently confronted with water scarcity, took similar measures. Based on a centuries-old myth of an underground river below the city (the so-called Diana), city councilors apparently authorized digging in a local church in an attempt to find this underground waterway in April 1305, 1 year after the end of the drought (Bargagli Petrucci, 1906, II, p. 20). This was not their first attempt to alleviate the drought's effects. In the spring of 1303, when a dearth of grain was already affecting Siena, the city council decided to import grain via the small port of Talamone, $100 \mathrm{~km}$ southwest of Siena (ASS, CG 62, 26 March 1303, c. 99) as they had done the previous year. In September 1303, however, after the grain imports had made food once again abundant in the city, the city council decided to buy the port for the republic and invested heavily in its refurbishment and expansion in the following years (Sordini, 2000, 73-112). Sienese citizens were relocated to the newly designed city complete with infrastructure and military fortifications (Fig. 12). Although the Sienese had discussed buying the port years before, it was the drought experience and the associated food scarcity that finally sparked the realization of these plans and led to a long-term investment in in- frastructure, which was quite possibly the most expensive project the Republic of Siena ever financed outside the capital's walls.

\subsection{Cultural aspects of drought}

Siena's attempts to develop infrastructure in response to the drought caught the attention of the Florentine poet Dante Alighieri, who mocked the Sienese in his Divine Comedy: "You will see them [some Florentines] among that vain people [the Sienese] who place their hopes in Talamone and will lose more hope in it than in seeking the Diana" (Dante, Divine Comedy, Purgatory, canto XIII, transl. Durling, 2003, p. 213). The Purgatory, finished during the early 1310s, makes clear that the futile efforts of the Sienese to search for their underground river did not go unnoticed by their neighbors. Nor did the Florentines ignore the acquisition of Talamone, having themselves experienced in 1303-1304 how vital the port was for their own food security, too. They negotiated a trade agreement with Siena, signed in August 1311, that guaranteed Florentine access to the maritime grain trade via Talamone, although under conditions very beneficial for Siena (Banchi, 1871, pp. 126-127).

In another famous medieval text, the De regimine principum, a kind of manual on good governance - or so-called 


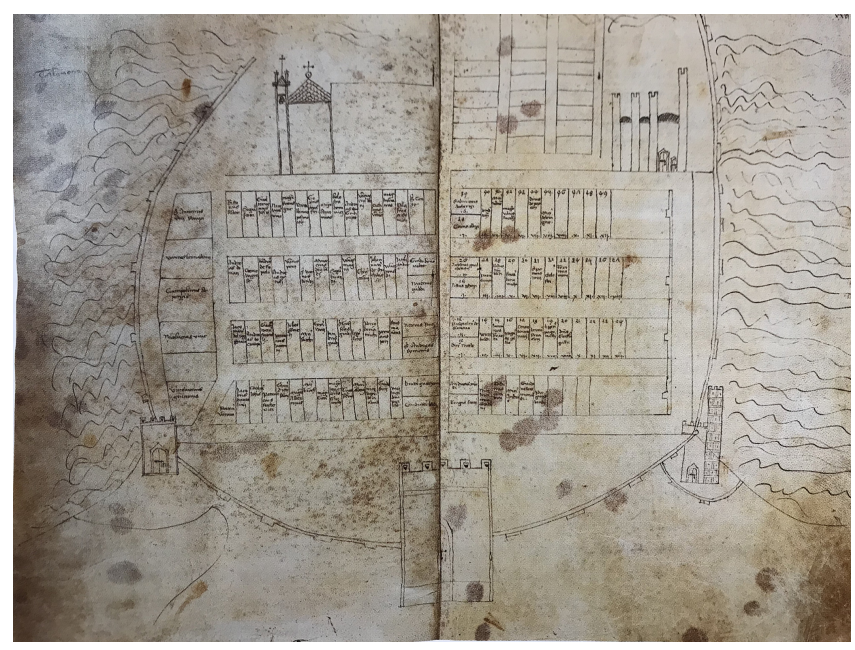

Figure 12. New city layout of Talamone with plots for new settlers from the mother city. Source: Archivio di Stato di Siena, Caleffo Nero, cap 3, 21 December 1306.

"mirror of princes" - by Thomas Aquinas and Ptolemy of Lucca, the latter starts writing from 1302 onwards and reflects on the importance of food security: "Food that is sold is not as effective for nourishment as it should be, since it is often adulterated. As Solomon says in Proverbs: 'Drink water from your own cistern,' which includes all nourishment, but especially drink, because it can more easily be adulterated. [...] There is greater security in using one's own food, since outsiders can easily poison something not kept in its proper storehouse or pantry, and it is more likely to be harmful" (Blythe, 1997, p. 114). That Ptolemy of Lucca wrote about the drought in his chronicle (Clavuot, 2009, p. 652), while he was also working on the mirror of princes, makes a connection between the two texts even more plausible.

\subsection{Societal responses to water scarcity}

While the concerns expressed in De regimine principum were theoretical, medieval civilizations had a very real stake in the matter. In times of drought, communities that lacked any efficient water system were confronted with the issue of how to acquire and distribute potable water. According to chronicles, some French rural communities faced severe hardships during an extreme drought in 1137, when people were forced to walk for miles in search of water (Labbé, 2018). The problem was further complicated by the fact that water sources were frequently contaminated, especially when temperatures soared and water levels fell and stagnated in summertime. It is thus hardly surprising that, according to the account of a chronicler in Paris, an epidemic broke out in the summer of 1307, after 3 years of drought, because the vineyard had suffered a late frost in April of the previous year, forcing the city's residents to drink water instead of wine (Buchon, 1827, p. 130). Pribyl (2017) has suggested that the outbreak of such epidemics 1 year after a warm summer half year, as the summer of 1306 likely was, may be one of the most typical consequences of such climatic conditions. The epidemic in Paris in 1307, caused by warm conditions paired with a wine shortage, can thus probably be interpreted as a result of the successive years of drought from 1304 to 1306.

Another side effect of major droughts in the 14th century was the temporary interruption of production and sometimes even shipping routes. Although drought did not generally imperil the harvest itself, at least in the regions north of the Alps, the lack of water sometimes indirectly disrupted the entire food supply system in that mills could not turn grain into flour and transportation from production regions to city markets was more difficult. These complications had economic consequences, as described by the Dominican monk of Colmar in 1304: although wheat that year was quite affordable because of benevolent harvests, bread was simultaneously quite expensive and scarce, because mills along dry rivers could not work anymore. Similarly, while wine growers were able to produce wine of very good quality, because the grapes contained a lot of sugar, they could not benefit from it. Wine prices actually remained very low since shipments could not be sent down the Rhine to the usual city markets of Strasbourg, Cologne, and Trier (Jaffé, 1861, p. 231).

\section{Discussion}

\subsection{Reassessing dendrochronological data with dense documentary information}

Surprisingly, the outcome of the correlation between droughts and fires for $\mathrm{CE}$ varies depending on which source one uses for the drought data. The correlation according to the data contained in the OWDA is quite insignificant $(r=-0.06)$, while a correlation based on drought indices in written sources is much better $(r=0.379)$. The data on the fires were constant in both calculations. The difference can be explained by the discrepancy between the reconstruction from the OWDA and the drought indices: the OWDA (even more so the maps it provides) shows considerably more dry periods than the documentary data, which emphasize the extraordinary events. Regarding the misleading picture the OWDA gives for Italy (in comparison with a reconstruction on the basis of written sources; see Sect. 4.1), a general comparison with reconstructions from written sources would be advisable, especially for those regions and periods for which there is a wealth of written sources and lack of dendroclimatological data (like for Italy).

\subsection{Drought impacts on agricultural production}

Experimental archeology has demonstrated the impacts of drought on medieval agricultural techniques (Kropp, 2019): considerable damage to summer crops but stable harvests from winter crops. A mixture of different crops taken to- 
gether guaranteed a sufficient harvest. This can explain the average cereal yields in Fig. 5, especially in 1304. In contrast, excessive humidity in 1310 and 1314-1316 clearly had a negative impact on the harvest (cereals $-20 \% /-40 \%$ and wine $-80 \% /-60 \%$, respectively). Methodologically, it is worth noting that cold episodes are reflected more reliably in agricultural proxy data than dry periods.

\subsection{Drought, fires, and the development of firefighting}

There is no clear connection between the experiences of the urban fires in the first decade of the 14th century and the development of organized firefighting. The first (yet very limited) fire prevention policies are known from 1325 (Contessa, 2000, pp. 21-27) and consisted of the introduction of brick chimneys and stoves. As early as 1296 onwards, the city of Siena reimbursed citizens who ruined their tools fighting fires (Bellissima, 1922), and when the city experienced two fires in November 1302, more than 200 people fought the fire in an organized way and used more than 1800 buckets of water (Di Tura del Grasso, 1939, p. 265). These are strong indicators of a proto fire-guard system in Italian city-states around 1300 , even prior to the establishment of official fire guards, for example, between 1344 and 1348 in Florence (Contessa, 2000, pp. 31-48).

\subsection{Putting the 1302-1307 drought period in global perspective for the 13th and 14th centuries}

According to our reconstruction of indices from narrative sources, no such multi-seasonal droughts or comparable events on a supraregional scale did occur during the 13th century, and after the drought in the first decade of the century, there is no comparable event until the 1360-1362 drought, which stretched across Europe, affecting central Europe (Brázdil et al., 2019, pp. 82-83; Kiss 2017, pp. 44-45; Bauch, 2017, pp. 1102-1104) and England (Pribyl, 2017, pp. 102-104) in 1360-1361, and the Balkan Peninsula and areas around the Black Sea and the Aegean Sea (Kiss and Nicolić, 2015, pp. 13-14) in 1362. Given the administrative data suggesting abnormally dry conditions in Catalonia in 1361-1362 (Fynn-Paul, 2016, p. 137), it seems plausible that a major city fire in Urgell (Battle, 1999, pp. 79-82) was linked to a continuous lack of precipitation. There are even indicators that this event had a global dimension: the years 1360 and 1362 were characterized in Japan by major droughts that caused famines there (Farris, 2006, p. 109); the Korean Peninsula (Robinson, 2009, p. 163) and western Rajasthan (Rao, 2009, p. 19) have been shown to have experienced similar conditions during this period.

\section{Conclusions}

In recent years, the wet anomaly of the 1310s has attracted a lot of attention from scholars (Slavin, 2019), who com- monly interpret it as a signal of the transition between the MCA and the LIA (Campbell, 2016). The huge variability that can be observed during this decade, like the high interannual variability observed in the 1340s, has been highlighted as a side effect of this rapid climate change. In the context of global warming, specialists now agree that periods of rapid climate change are accompanied by a higher probability and frequency of extreme events (Sippel and Otto, 2014; Otto et al., 2016). To date, in the field of medieval climate history, no efforts have been made to examine the remarkable period of drought in the first decade of the 14th century. However, we have demonstrated that two exceptional series of warm, dry summer half years occurred during this period - in the Mediterranean Italian region between 1302 and 1304, and north of the Alps from 1304 to 1306.

Might the remarkable drought conditions of 1302-1307, combined with the cold anomalies of the 1310s and the 1340s, be viewed as part of the climatic transition from the MCA to the LIA, as well? The dry anomaly of the 1300s was more than a last glow of the MCA. Together with the wetcold anomaly of the 1310s one might speak of a "long" Dantean Anomaly, which provides a much more substantial, if not entirely new, starting point for the changing climatic patterns of this period. Our reconstruction of the predominant weather patterns for the first decade of the 14th century based on both documentary and proxy data - points to multiple European precipitation seesaw events from 1302 to 1307, which may have even affected the eastern Mediterranean.

The series of reported meteorological conditions for this period show similarities to the seesaw conditions which prevailed in 2018 over continental Europe (Toreti et al., 2019). The period under study was characterized by a series of enduring, steady precipitation dipoles which led regionally to stark contrasts of extreme precipitation and drought. It can be debated to which extent the $1302-1307$ period can be compared to what is currently discussed regarding the influence of the Arctic amplification phenomenon (Cohen et al., 2014) on the increasing frequency of persistent, stable weather patterns that have occurred since the late 1980s. Arctic amplification describes the decrease of the latitudinal temperature gradient between the midlatitudes and the Arctic, which was found to weaken the storm tracks, shift the jet streams, and amplify quasi-stationary synoptic-scale atmospheric waves (Coumou et al., 2018). Future studies should investigate whether such a scenario was also present in the early 14th century during the transition from the MCA to the LIA. It appears plausible that such a climatological transition could be temporally associated with a reduced latitudinal temperature gradient and have consequences similar to the current phase of Arctic amplification.

Careful critical analysis of written historical sources provide a useful mechanism to refine the chronology of extreme events in combination with natural proxy data. As we have demonstrated, the OWDA tree-ring reconstruction has gaps in the information due to scarce raw data, especially for 
southern Europe. Using narrative and administrative sources, which are sufficiently numerous from the 14th century onward, historians can more accurately discern this epoch's climate, including the winter conditions that must be taken into consideration to get a full image of the droughts' extent.

Finally, droughts deserve more attention from cultural historians of climate than just the analysis of religious mitigation strategies. Both contemporary perceptions and analysis of the historical data suggest a connection to fires, which were a major threat to medieval cities. Our analysis shows, for the first time, a correlation between droughts and fires over the course of 200 years and suggests that the increased fire danger lagged a year behind the climatic phenomenon. In addition, droughts provoked unusual reflections on thirst and the use of water that are otherwise rare in medieval texts.

Data availability. All the data used to perform the analysis in this study are described and properly referenced in the paper.

Supplement. The supplement related to this article is available online at: https://doi.org/10.5194/cp-16-2343-2020-supplement.

Author contributions. MB provided the general conceptualization, curation, and analysis of the Italian historical sources, in addition to the creation, evaluation, and visualization of drought indices and city fires; he also wrote the initial draft and led the funding acquisition. TL provided conceptual input, curation, and analysis of the French historical sources and the visualization of other agricultural proxies. AE provided curation and analysis of the central European material and conceptual input on data presentation. PS provided conceptual input on climatological backgrounds, meteorological analysis, and the interpretation of documentary data on weather patterns and geopotential maps.

Competing interests. The authors declare that they have no conflict of interest.

Special issue statement. This article is part of the special issue "Droughts over centuries: what can documentary evidence tell us about drought variability, severity and human responses?". It is not associated with a conference.

Acknowledgements. Martin Bauch, Thomas Labbé, and Annabell Engel were supported by a Freigeist Fellowship funded by the Volkswagen Foundation, which also covered the publication costs. We thank Andreas Görlitz (Siegen) for assistance with crosscorrelation techniques and advice on statistical issues. Emanuela Guidoboni (Bologna) generously gave us access to her unpublished climate historical collection for the Italian case studies. The first idea on this topic was presented and developed during the workshop Ladenburger Diskurs: "Katastrophen im Spannungsfeld von Kultur,
Umwelt und Technik: Hitze, Hunger und Durst Dürrekatastrophen im mediterranen Raum", Daimler and Benz Foundation, 3 March 2017, Ladenburg (Germany), organized by Gerrit J. Schenk (Darmstadt). Finally, we are thankful for input from and discussion with colleagues from the PAGES (Past Global Changes) Working Group CRIAS, especially Chantal Camenisch, Rudolf Brázdil, and Andrea Kiss during the October 2019 workshop of CRIAS in Leipzig (Germany). Finally, we warmly thank Ellen Yutzy Glebe (Kassel) for her invaluable copy-editing of this article and Lina Lerch (Leipzig) for technical assistance with LaTeX.

Financial support. This publication has been funded by the Volkswagen Foundation from the Freigeist Fellowship "The Dantean Anomaly".

Review statement. This paper was edited by Stefan Grab and reviewed by Christian Rohr and one anonymous referee.

\section{References}

Alexandre, P.: Le climat en Europe au Moyen Age: Contribution à l'histoire des variations climatiques de 1000 à 1425 , d'après les sources narratives de l'Europe occidentale, Recherches d'histoire et de sciences sociales 24, Éditions de l'école des hautes études en sciences sociales, Paris, France, 1987 (in French).

Andres, H. J. and Peltier, W. R.: Regional Influences of Natural External Forcings on the Transition from the Medieval Climate Anomaly to the Little Ice Age, J. Clim., 29, 5779-5800, https://doi.org/10.1175/JCLI-D-15-0599.1, 2016.

ASS CG 62: Archivio di Stato di Siena - Consiglio Generale - Deliberazioni: vol. 62 (1302 dicembre 7-1303 giugno 29) (in Latin)

Banchi, L.: I porti della Maremma senese durante la repubblica. Narrazione storica con documenti inediti, Leo S. Olschki, Firenze, Italy, 1871 (in Italian).

Bargagli Petrucci, F.: Le Fonti di Siena e il loro acquedotti. Note storiche dalle origini fino al MDLV, vol. 2, documenti, Leo Olschki, Siena, Italy, 1906 (in Italian).

Battle, C.: Destructions naturelles des villes de la Couronne d'Aragon au Bas Moyen Âge, in: Zerstörung durch Erdbeben, Feuer und Wasser. Destruction by earthquakes, fire and water $=$ Destructions par des tremblements de terre, le feu et l'eau, StadtzerstÓrung und Wiederaufbau $=$ Destruction and reconstruction of towns 1, edited by: Körner, M., Haupt, Bern, Switzerland, 67-86, 1999 (in French).

Bauch, M.: Jammer und Not. Karl IV. und die natürlichen Rahmenbedingungen des 14. Jahrhunderts, Český Časopis Historický, 115, 983-1016, 2017 (in German).

Bellissima, G.: L'estinzione degli incendi secondo lo Statuto del Comune di Siena del XXI decembre MCCLXXXXVI, Stab. Tip. S. Bernardino, Siena, Italy, 1922 (in Italian).

Bitterli, M.: Es brennt ein Licht in der Hütte. Beleuchtungseinrichtungen im mittelalterlichen Alltag - ein Überblick, in: Feuernutzung und Brand in Burg, Stadt und Kloster im Mittelalter und in der Frühen Neuzeit, edited by: Wagener, O., Michael Imhof Verlag, Petersberg, Germany, 330-339, 2015 (in German). 
Blythe, J. M.: On the Government of Rulers/De Regimine Principum. Ptolemy of Lucca with portions attributed to Thomas Aquinas, University of Pennsylvania Press, Philadelphia, USA, 1997.

Bonazzi, G.: Chronicon Parmense. Ab Anno MXXXVIII usque ad Annum MCCCXXXVIII., Rerum Italicarum Scriptores (RIS ${ }^{2}$ ), 9/9, Lapi, Città di Castello, Italy, 1902 (in Latin/Italian).

Bothe, O., Wagner, S., and Zorita, E.: Inconsistencies between observed, reconstructed, and simulated precipitation indices for England since the year $1650 \mathrm{CE}$, Clim. Past, 15, 307-334, https://doi.org/10.5194/cp-15-307-2019, 2019.

Bowsky, W. M.: A medieval Italian commune. Siena under the Nine, 1287-1355, University of California Press, Berkeley, USA, 1981.

Bradley, R. S., Hughes, M. K., and Diaz, H. F.: Climate Change: Climate in Medieval Time, Science, 302, 404-405, https://doi.org/10.1126/science.1090372, 2003.

Brázdil, R. and Kotyza, O.: History of Weather and Climate in the Czech Lands I: Period 1000-1500, Zürcher geographische Schriften 62, Geographisches Institut ETH, Zürich, Switzerland, 1995.

Brázdil, R., Dobrovolný, P., Trnka, M., Kotyza, O., Řezníčková, L., Valášek, H., Zahradníček, P., and Štěpánek, P.: Droughts in the Czech Lands, 1090-2012 AD, Clim. Past, 9, 1985-2002, https://doi.org/10.5194/cp-9-1985-2013, 2013.

Brázdil, R., Kiss, A., Luterbacher, J., Nash, D. J., and Řezníčková, L.: Documentary data and the study of past droughts: a global state of the art, Clim. Past, 14, 1915-1960, https://doi.org/10.5194/cp-14-1915-2018, 2018.

Brázdil, R., Kiss, A., Řezníčková, L., and Barriendos, M.: Droughts in historical times in Europe, as derived from documentary evidence, in: Palaeohydrology: Traces, tracks and trails of extreme events, edited by: Herget, J. and Fontana, A., Springer, Cham, 65-96, https://doi.org/10.1007/978-3-030-23315-0_4, 2019.

Brown, N.: History and climate change. A eurocentric perspective, Routledge, London, UK, 2001.

Buchon, J. A.: Chronique métrique de Godefroy de Paris, suivie de la taille de Paris en 1313, in: Collection des chroniques nationales françaises, 9, Verdière, Paris, France, 1-304, 1827 (in French).

Camenisch, C.: Endlose Kälte. Witterungsverlauf und Getreidepreise in den Burgundischen Niederlanden im 15. Jahrhundert, Wirtschafts-, Sozial- und Umweltgeschichte 5, Schwabe, Basel, Switzerland, 2015 (in German).

Camenisch, C. and Salvisberg, M.: Droughts in Bern and Rouen from the 14th to the beginning of the 18th century derived from documentary evidence, Clim. Past, 16, 2173-2182, https://doi.org/10.5194/cp-16-2173-2020, 2020.

Camenisch, C., Brázdil, R., Kiss, A., Pfister, C., Wetter, O., Rohr, C., Contino, A., and Retsö, D.: Extreme heat and drought in 1473 and their impacts in Europe in the context of the early 1470s, Reg. Environ. Change, 20, 19, https://doi.org/10.1007/s10113020-01601-0, 2020.

Campbell, B. M. S.: The great transition: Climate, disease and society in the late-medieval world, Cambridge University Press, Cambridge, 2016.

Campbell, B. M. S.: Three centuries of English crops yields, 12111491, available at: http://www.cropyields.ac.uk (last access: 20 February 2020), 2007.
Chalyan-Daffner, K.: Natural disasters in Mamlūk Egypt (12501517). Perceptions, interpretations and human responses, $\mathrm{PhD}$ thesis, Ruprecht-Karls-Universität Heidelberg, Germany, 2013.

Clavuot, O.: Tholomeus von Lucca. Historia ecclesiastica nova nebst Fortsetzungen bis 1329, Hahnsche Buchhandlung, Hannover, Germany, 2009 (in German/Latin).

Cohen, J., Screen, J., Furtado, J. C., Barlow, M., Whittleston, D., Cornou, D., Francis, J., Dethloff, K., Entekhabi, D., Overland, J., and Jones, J.: Recent Arctic amplification and extreme mid-latitude weather, Nat. Geosci., 7, 627-637, https://doi.org/10.1038/ngeo2234, 2014.

Contessa, M. P.: L’Ufficio del fuoco nella Firenze del Trecento, Le Lettere, Firenze, Italy, 2000 (in Italian).

Cook, E. R., Seager, R., Kushnir, Y., Briffa, K. R., Büntgen, U., Frank, D., Krusic, P. J., Tegel, W., van der Schrier, G., AndreuHayles, L., Baillie, M., Baittinger, C., Bleicher, N., Bonde, N., Brown, D., Carrer, M., Cooper, R., Čufar, K., Dittmar, C., Esper, J., Griggs, C., Gunnarson, B., Günther, B., Gutierrez, E., Haneca, K., Helama, S., Herzig, F., Heussner, K.-U., Hofmann, J., Janda, P., Kontic, R., Köse, N., Kyncl, T., Levanič, T., Linderholm, H., Manning, S., Melvin, T. M., Miles, D., Neuwirth, B., Nicolussi, K., Nola, P., Panayotov, M., Popa, I., Rothe, A., Seftigen, K., Seim, A., Svarva, H., Svoboda, M., Thun, T., Timonen, M., Touchan, R., Trotsiuk, V., Trouet, V., Walder, F., Ważny, T., Wilson, R., and Zang, C.: Old World megadroughts and pluvials during the Common Era, Sci. Adv., 1, e1500561, https://doi.org/10.1126/sciadv.1500561, 2015.

Coumou, D., Di Capua, G., Vavrus, S., Wang, L., and Wang, S.: The influence of Arctic amplification on mid-latitude summer circulation, Nat. Commun., 9, 2959, https://doi.org/10.1038/s41467018-05256-8, 2018.

Curschmann, F.: Hungersnöte im Mittelalter: Ein Beitrag zur deutschen Wirtschaftsgeschichte des 8. bis 13. Jahrhunderts, Leipziger Studien aus dem Gebiet der Geschichte 6, bd. 1, B. G. Teubner, Leipzig, Germany, 1900 (in German).

Di Tura del Grasso, A.: Cronaca senese attribuita ad Agnolo di Tura del Grasso detta la Cronica Maggiore, in: Cronache senese, vol. 1, Rerum Italicarum Scriptores (RIS ${ }^{2}$ ), 15, 6:1-2, edited by: Lisini, A. and Iacometti, F., Zanichelli, Bologna, Italy, 253-564, 1939 (in Italian).

Durling, R. M.: The Divine Comedy of Dante Alighieri, vol. 2: Purgatorio, Oxford University Press, Oxford, UK, 2003.

Farris, W. W.: Japan's medieval population. Famine, fertility, and warfare in a transformative age, Univ. of Hawai'i Press, Honolulu, Hawaii, USA, 2006.

Fynn-Paul, J.: The rise and decline of an Iberian bourgeoisie: Manresa in the later Middle Ages, 1250-1500, Cambridge studies in medieval life and thought, 4th ser., 103, Cambridge University Press, Cambridge, UK, 2016.

Garnier, E.: Historic drought from archives: beyond the instrumental record, in: Drought. Science and Policy, edited by: Iglesias, A., Assimacopoulos, D., and Van Lanen, H. A. J., Wiley, Hoboken, USA, 45-67, 2019.

Glaser, R.: Klimageschichte Mitteleuropas, 1200 Jahre Wetter, Klima, Katastrophen: Mit Prognosen für das 21. Jahrhundert, 3rd Edn., Primus, Darmstadt, Germany, 2013 (in German).

Griggs, C., DeGaetano, A., Kuniholm, P., and Newton, M.: A regional high-frequency reconstruction of May-June precipitation in the north Aegean from oak tree rings, A.D. 1089-1989, Int. 
J. Climatol., 27, 1075-1089, https://doi.org/10.1002/joc.1459, 2007.

Grove, J. M.: The Initiation of the "Little Ice Age" in Regions Round the North Atlantic, Climatic Change, 48, 53-82, https://doi.org/10.1023/A:1005662822136, 2001.

Huschner, W., Münch, E., Neustadt, C., and Wagner, W. E.: Mecklenburgisches Klosterbuch: Handbuch der Klöster, Stifte, Kommenden und Prioreien (10./11.-16. Jahrhundert), Hinstorff, Rostock, Germany, 2016 (in German).

Jaffé, P.: Annales Colmarienses maiores a. 1277-1472, in: Monumenta Germaniae Historica, Scriptores (in folio), 17, edited by: Pertz, G. H., Hahnsche Buchhandlung, Hannover, Germany, 202-232, 1861 (in Latin).

Jankrift, K. P.: Brände, Stürme, Hungersnöte. Katastrophen in der mittelalterlichen Lebenswelt, Jan Thorbecke Verlag, Ostfildern, Germany, 2003 (in German).

Jordan, W. C.: The great famine: Northern Europe in the early fourteenth century, Princeton University Press, Princeton, USA, 1996.

Keyser, E.: Deutsches Städtebuch. Handbuch städtischer Geschichte, vol. 12, Kohlhammer, Stuttgart, Germany (revised editions: Stoob, H., Johannek, P., Engel, E., Enders, L., Heinrich, G., Schich, W., and Post, F. J.: 1995-2003), 1939-1974.

Kiss, A.: Weather and Weather-Related Natural Hazards in Medieval Hungary III: The Fourteenth Century, Medium Aevum, 73, 5-55, 2016.

Kiss, A.: Droughts and low water levels in late medieval Hungary II: 1361, 1439, 1443-4, 1455, 1473, 1480, 1482(?), 1502-3, 1506: Documentary versus tree-ring (OWDA) evidence, Journal of Environmental Geography, 10, 43-56, https://doi.org/10.1515/jengeo-2017-0012, 2017.

Kiss, A.: Floods and Long-Term Water-Level Changes in Medieval Hungary, Springer, Cham, Germany, 2019.

Kiss, A. and Nicolić, Z.: Droughts, Dry Spells and Low Water Levels in Medieval Hungary (and Croatia) I: The Great Droughts of 1362, 1474, 1479, 1494 and 1507, J. Environ. Geogr., 8, 11-22, https://doi.org/10.1515/jengeo-2015-0002, 2015.

Knittler, H., Deák, E., Baltzarek, F., Pradel, J., Goldmann, F., Oberhammer, E., Hye, F.-H., Hausmann, R. F., and Reisinger, N.: Österreichisches Städtebuch, Verlag der Österreichischen Akademie der Wissenschaften, Wien, Austria, 1968-2001 (in German).

Kropp, C.: Die Dürre des Jahres 2018 aus der Perspektive mittelalterlicher Subsistenzwirtschaft. Erste Erfahrungen aus dem experimentalarchäologischen Freilichtmuseum Lauresham, Laureshamensia, 2, 6-17, 2019 (in German).

Labbé, T.: Europe, 1137 AD: Drought, fires and thirst, available at: https://dantean.hypotheses.org/645 (last access: 26 February 2020), 2018.

Le Roy Ladurie, E.: Histoire humaine et comparée du climat. I. Canicules et glaciers (XIIIe-XVIIIe siècles), Fayard, Paris, France, 2004 (in French).

Malewicz, M. H.: Zjawiska przyrodnicze w relacjach dziejopisarzy polskiego średniowiecza, Monografie z dziejów nauki i techniki, 123, Zakł. Nar. im. Ossolińskich, Wrocław, Poland, 1980 (in Polish/Latin).

Martín-Vide, J. and Barriendos Vallvé, M.: The use of rogation ceremony records in climatic reconstruction: a case study from Catalonia (Spain), Climatic Change, 30, 201-221, https://doi.org/10.1007/BF01091842, 1995.

Mauelshagen, F.: Klimageschichte der Neuzeit. 1500-1900, WBG, Darmstadt, Germany, 2010 (in German).

Munzar, J.: Extreme droughts in Central Europe in the preinstrumental period, Morav. Geogr. Rep., 12, 13-23, 2004.

Nunn, P. D.: Climate, Environment and Society in the Pacific during the last Millenium, Elsevier, Amsterdam, Netherlands, 2007.

Otto, F. E. L., van Oldenborgh, G. J., Eden, J., Stott, P. A., Karoly, D. J., and Allen, M. R.: The attribution question, Nat. Clim. Change, 6, 813-816, https://doi.org/10.1038/nclimate3089, 2016.

Pfister, C.: Wetternachhersage. 500 Jahre Klimavariationen und Naturkatastrophen (1496-1995), Haupt Verlag, Bern, Switzerland, 1999 (in German).

Pfister, C.: The "Black Swan" of 1540. Aspects of a European megadrought, in: Climatic change and cultural transition in Europe, edited by: Leggewie, K. and Mauelshagen, F., Brill, Leiden, Netherlands, 156-196, 2018.

Pfister, C., Schwarz-Zanetti, G., and Wegmann, M.: Winter severity in Europe: The fourteenth century, Climatic Change, 34, 91-108, https://doi.org/10.1007/BF00139255, 1996.

Pfister, C., Camenisch, C., and Dobrovolný, P.: Analysis and interpretation: temperature and precipitation indices, in: The Palgrave Handbook of Climate History, edited by: White, S., Pfister, C., and Mauelshagen, F., Palgrave Macmillan, London, UK, 115129, 2018.

Pribyl, K.: Farming, Famine and Plague. The Impact of Climate in Late Medieval England, Cham, Springer, Germany, 2017.

Pribyl, K., Cornes, R., and Pfister, C.: Reconstructing Medieval April-July Mean Temperatures in East Anglia, 1256-1431, Climatic Change, 113, 393-412, https://doi.org/10.1007/s10584011-0327-y, 2012.

Rao, A. S.: Climate and microclimate changes influencing the fauna of the hot indian arid zone, in: Faunal ecology and conservation of the great Indian Desert, edited by: Sivaperuman, C., Baqri, Q. H., Ramaswamy, G., and Naseema, M., Springer, Berlin, Heidelberg, Germany, 13-24, 2009.

Raphael, S. K.: Climate and political climate. Environmental disasters in the medieval Levant, Brill, Leiden, Boston, Netherlands, USA, 2013.

Riegg, E.: Brandkatastrophen und stadtbürgerliche Identität, Traverse, 10, 130-141, 2003 (in German).

Robinson, D. M.: Empire's twilight: Northeast Asia under the Mongols, Harvard-Yenching Institute monograph series, 68, Harvard Univ. Press, Cambridge, Mass., 2009.

Rohr, C., Camenisch, C., and Pribyl, K.: European Middle Ages, in: The Palgrave handbook of climate history, edited by: White, S., Pfister, C., and Mauelshagen, F., Palgrave Macmillan, London, UK, 247-263, 2018.

Slavin, P.: The 1310s event, in: The Palgrave handbook of climate history, edited by: White, S., Pfister, C., and Mauelshagen, F., Palgrave Macmillan, London, UK, 495-516, 2018.

Slavin, P.: Experiencing famine in Fourteenth-Century Britain, Brepols, Turnhout, Belgium, 2019.

Sippel, S. and Otto, F. E. L.: Beyond climatological extremes - assessing how the odds of hydrometeorological extreme events in South-East Europe change in a warming climate, Climatic Change, 125, 381-398, https://doi.org/10.1007/s10584014-1153-9, 2014. 
Sordini, B.: Il Porto della "Gente vana". Lo scalo di Talamone tra il secolo XIII e il secolo XV, Protagon Editori Toscani, Siena, Italy, 2000 (in Italian).

Steinhilber, F., Beer, J., and Fröhlich, C.: Total solar irradiance during the Holocene, Geophys. Res. Lett., 36, 2130, https://doi.org/10.1029/2009GL040142, 2009.

Stone, D.: The impact of drought in early fourteenthcentury England, Econ. Hist. Rev., 67, 435-462, https://doi.org/10.1111/1468-0289.12035, 2014.

Telelis, I. G.: Meteoroloyiká phainómena kai klíma sto Vizántio, vol. 2, Akademia Athinon, Athens, Greece, 2004 (in Modern Greek).

Titow, J.: Evidence of weather in the accounts of the Bishopric of Winchester 1209-1350, Econ. Hist. Rev., 12, 360-407, 1960.

Toreti, A., Belward, A., Perez-Dominguez, I., Naumann, G., Luterbacher, J., Cronie, O., Seguini, L., Manfron, G., Lopez-Lozano, R., Baruth, B., Berg, M., Dentener, F., Ceglar, A., Chatzopoulos, T., and Zampieri, M.: The Exceptional 2018 European Water Seesaw Calls for Action on Adaptation, Earths Future, 7, 652663, https://doi.10.1029/2019EF001170, 2019.

Vadas, A.: Weather Anomalies and Climatic Change in Late Medieval Hungary: Weather events in the 1310s in the Hungarian Kingdom, VDM Verlag, Saarbrücken, Germany, 2010.

Varanini, G. and Baldassari, G.: Racconti esemplari di predicatori del Due e Trecento, vol. 2, I novellieri italiani, 4, Salerno, Roma, Italy, 1993 (in Italian).

Vogt, S., Glaser, R., Kahle, M., Hologa, R., Münch, L., and Erfurt, M.: The Grotzfeld Data Set - Coded Environmental, Climatological and Societal data for the Near and Middle East from $\mathrm{AD} 801$ to 1821 , in: tambora.org data series 1, edited by: Glaser, R; Kahle, M., and Hologa, R., https://doi.org/10.6094/tambora.org/2016/c156/serie.pdf, 2016.

Wattenbach, W.: Continuatio Novimontensis a. 1329-1396, in: Monumenta Germaniae Historica, Scriptores (in folio) 9, edited by: Pertz, G. H., Hahnsche Buchhandlung, Hannover, Germany, 669-677, 1851a (in Latin).

Wattenbach, W.: Continuatio Sancrucensis II a. 1234-1266, in: Monumenta Germaniae Historica, Scriptores (in folio) 9, edited by: Pertz, G. H., Hahnsche Buchhandlung, Hannover, Germany, 637-646, 1851b (in Latin).

Weikinn, C.: Quellentexte zur Witterungsgeschichte Europas von der Zeitwende bis zum Jahre 1850: Hydrographie, Quellensammlung zur Hydrographie und Meteorologie, Akad.-Verl., Berlin, Germany, 1958 (in German).
Weikinn, C.: Katastrophale Dürrejahre während des Zeitraums 1500-1850 in den Flußgebieten der heutigen Deutschen Demokratischen Republik, Ac. Hydrophys., 10, 33-54, 1965/66 (in German).

Weikinn, C.: Weikinn'sche Quellensammlung zur Witterungsgeschichte Europas (Meteorologischer Teil), https://doi.org/10.6094/UNIFR/11658, 2017.

Wetter, O. and Pfister, C.: An underestimated record breaking event - why summer 1540 was likely warmer than 2003, Clim. Past, 9, 41-56, https://doi.org/10.5194/cp-9-41-2013, 2013.

Wetter, O., Pfister, C., Werner, J. P., Zorita, E., Wagener, S., Seneviratne, S. I., Herget, J., Grünewald, U., Luterbacher, J., Alcoforado, M.-J., Barriendos, M., Bieber, U., Brázdil, R., Burmeister, K. H., Camenisch, C., Contino, A., Dobrovolný, P., Glaser, R., Himmelsbach, I., Kiss, A., Kotyza, O., Labbé, T., Limanówka, D., Litzenburger, L., Nordli, Ø., Pribyl, K., Retsö, D., Riemann, D., Rohr, C., Siegfried, W., Söderberg, J., and Spring, J.-L.: The year-long unprecedented European heat and drought of 1540 - a worst case, Climatic Change, 125, 349-363, https://doi.org/10.1007/s10584-014-1184-2, 2014.

White, S.: The Real Little Ice Age, J. Interdiscipl. Hist., 44, 327352, https://doi.org/10.1162/JINH_a_00574, 2014.

Wolf, T.: ... incensus est ignis. Wormser Stadtbrände des 13. Jahrhunderts in der chronikalischen Überlieferung, in: Feuernutzung und Brand in Burg, Stadt und Kloster im Mittelalter und in der Frühen Neuzeit, Studien zur internationalen Architekturund Kunstgeschichte 129, edited by: Wagener, O., Michael Imhof Verlag, Petersberg, Germany, 228-233, 2015 (in German).

Wozniak, T.: Brände im mittelalterlichen Nowgorod, Neues Osteuropa, 4, 8-23, 2011 (in German).

Wozniak, T.: Kirchen und Feuerschutz in Novgorod im Mittelalter, in: Feuernutzung und Brand in Burg, Stadt und Kloster im Mittelalter und in der Frühen Neuzeit, Studien zur internationalen Architektur- und Kunstgeschichte 129, edited by: Wagner, O., Michael Imhof Verlag, Petersberg, Germany, 234-243, 2015 (in German).

Zwierlein, C.: Der gezähmte Prometheus: Feuer und Sicherheit zwischen Früher Neuzeit und Moderne, Umwelt und Gesellschaft 3, Vandenhoeck \& Ruprecht, Göttingen, Germany, 2011 (in German). 